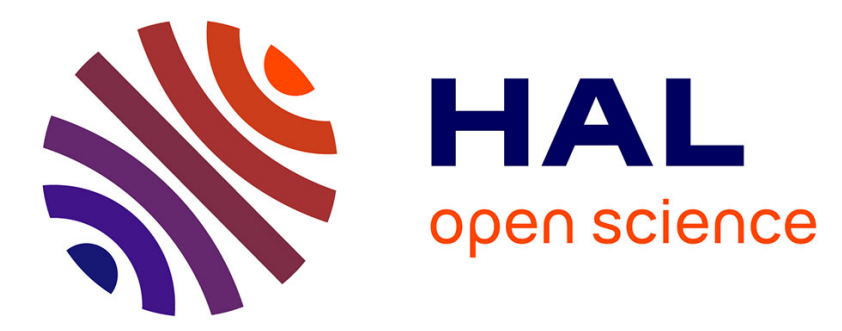

\title{
The Mediterranean oak forest: a new habitat for the Capercaillie?
}

\author{
Manuel A. González, Pedro P. Olea, Luis Robles, Vicente Ena
}

\section{To cite this version:}

Manuel A. González, Pedro P. Olea, Luis Robles, Vicente Ena. The Mediterranean oak forest: a new habitat for the Capercaillie?. Journal für Ornithologie = Journal of Ornithology, 2010, 151 (4), pp.901-906. 10.1007/s10336-010-0528-6 . hal-00588626

\section{HAL Id: hal-00588626 https://hal.science/hal-00588626}

Submitted on 25 Apr 2011

HAL is a multi-disciplinary open access archive for the deposit and dissemination of scientific research documents, whether they are published or not. The documents may come from teaching and research institutions in France or abroad, or from public or private research centers.
L'archive ouverte pluridisciplinaire HAL, est destinée au dépôt et à la diffusion de documents scientifiques de niveau recherche, publiés ou non, émanant des établissements d'enseignement et de recherche français ou étrangers, des laboratoires publics ou privés. 
The Mediterranean Quercus pyrenaica oak forest: a new habitat for the Capercaillie?

Manuel A. González ${ }^{1}$, Pedro P. Olea ${ }^{2}$, Luis Robles ${ }^{3}$, Vicente Ena ${ }^{1}$.

${ }^{1}$ Dpt. of Biodiversity and Environmental Management, University of León, Campus de Vegazana s/n, 24071 León, Spain.

${ }^{2}$ School of Biology, IE University, Campus Santa Cruz la Real, 40003 Segovia, Spain.

${ }^{3}$ Asociación para la Conservación del Urogallo (ACU), C/ Unic s/n, 24850 Baix Pallars (Buseu), Lleida, Spain.

*Corresponding author. Email: magong@unileon.es

Phone: +34 987291907 


\begin{abstract}
We described an extension of the known distribution range of capercaillie into an atypical area and habitat for the species. Nine Cantabrian capercaillie Tetrao urogallus cantabricus leks and 14 cocks were registered in Mediterranean Quercus pyrenaica forests in an area of $1,500 \mathrm{~km}^{2}$, of which 4,500 forest hectares were surveyed. At present this population represents both the southern-most distribution for capercaillie and the only one inhabiting Mediterranean $Q$. pyrenaica forests, what suggests a wider adaptation of this (sub)species than previously thought. This capercaillie population and its habitat need to be better studied, as well as to be considered in conservation planning for Cantabrian capercaillie.
\end{abstract}

KEY WORDS: conservation, leks, Mediterranean, Quercus pyrenaica, Tetrao urogallus cantabricus, plasticity. 
Populations across distribution range show different adaptations to local

3 conditions from the core areas to the periphery of their distribution (Guo et al.

4 2003). In the case of capercaillie, the vast majority of populations inhabit boreal

5 and montane coniferous forests with abundant bilberry Vaccinium myrtillus

6 understory (Storch 1993; 2000a; 2000b, Storch 2001). However, the Cantabrian

7 subspecies Tetrao urogallus cantabricus (Cantabrian Mountains, NW Spain)

8 resides mainly in pure deciduous forests of beech Fagus sylvatica, birch Betula

9 pubescens and sessile oak Quercus petraea, as well as mixed forests of beech and

10 oaks (Quercus robur, Q. petraea, and Q. pyrenaica) (Bañuelos \& Quevedo 2008).

11 In these forests holly Ilex aquifolium provides a key, evergreen winter food

12 resource for Cantabrian capercaillie (Storch 2001; Blanco-Fontao et al. 2009)

13 whereas it relies on bilberry in summer-autumn (Blanco-Fontao et al. 2009).

14 Previous studies showed, however, a negative selection to Quercus pyrenaica

15 forests by Cantabrian capercaillie at the northern slope of the Cantabrian range

16 (Quevedo et al. 2006b).

17 This endemic capercaillie subspecies is isolated and separated more than

$18300 \mathrm{~km}$ from the nearest capercaillie population in the Pyrenees. After severe

19 population decline in the last three decades (from 2,000 to 400 adults), only 108

20 leks remain occupied in the northern watershed and 85 leks in the southern,

21 corresponding to an overall occupancy rate of $32 \%$ of all known leks (Bañuelos \&

22 Quevedo 2008). Consequently, Cantabrian capercaillie subspecies qualifies to be

23 listed as "Endangered" according to the IUCN criteria (Storch et al. 2006).

24 Capercaillie populations have so far been generally considered to be

25 distributed in the Eurosiberian biogeographic region, outside Mediterranean 
26 region (but see Handrinos and Akriotis 1997, Storch 2001; discussion section).

27 Unlike the Eurosiberian region, the Mediterranean region is characterized by a

28 period of drought during hot summer which determines the existing vegetation

29 (e.g., Penas 1995; Blondel \& Aronson 1999; Rivas-Martínez et al. 2005). This

30 Mediterranean environment is thought to be unsuitable for a species primarily

31 adapted to boreal environments. However, there are historical records suggesting

32 capercaillie presence during 17th-19th centuries in Mediterranean areas in Spain

33 (Madoz 1848; Castroviejo 1975; Martínez 1993), but the first sighting record in

34 Q. pyrenaica forests in this Mediterranean area was unnoticed until May 1998

35 (Pollo et al. 2004) (No. 1 in Fig. 1).

36 In this study we present information on the number of cocks and

37 characteristics of leks located in an atypical area and habitat for the capercaillie,

38 i.e., Mediterranean $Q$. pyrenaica forests with virtual lack of bilberry and holly.

39 This study is the first showing capercaillie widely present in this forest type,

40 suggesting a wider ecological plasticity of this (sub)species than previously

41 thought. We also discuss implications that this new capercaillie site may have in

42 the conservation of Cantabrian capercaillie.

MATERIAL \& METHODS

Study area

The study area is located on the southern slope of the Cantabrian

47 Mountains in León province (NW Spain). It is centred at $42^{\circ} 39^{\prime} \mathrm{N}$ and located in

48 the Mediterranean biogeographical region bordering the Eurosiberian region

49 (Atlantic) (Rivas-Martínez et al. 2004, European Environment Agency, 2008)

50 (Fig. 1). The study area covers approximately $1,500 \mathrm{~km}^{2}$ below the putative line 
51 separating the two biogeographical regions in a landscape slightly mountainous

52 (elevation ranges from 800 to 1,700 m.a.s.l.). It belongs to the biogeographical

53 unit Carpetan-Leonese Subprovince from the Mediterranean region with

54 supramediterranean bioclimate (Penas 1995, Rivas-Martínez et al. 2005, del Río

55 et al 2007). A meteorological station from our study area (Villameca) clearly

56 shows two dry months $(P<2 T$; Blondel \& Aronson 1999) in summer: July $(P=26$;

$57 T=19.9)$ and August $(P=19 ; T=19.1)$ (data based on 37 years).

58 Dominant forests are supramediterranean natural (more than 50 years old) and

59 post-fire $Q$. pyrenaica forests frequently occurring interspersed with Scots pine

60 Pinus sylvestris plantations (less than 50 years old). Both forest types are largely

61 monoespecific in the study area. Q. pyrenaica forests cover 27,000 ha $(19 \%$ of the

62 study area). Scots pine plantations occupy 11,000ha (8\%).

63 Q. pyrenaica (Willd.) is a marcescent oak tree distributed widely in Spain

64 as well as the western part of France and the northwest of Marocco. This tree

65 develops under siliceous soils in Eurosiberian region as well as in the

66 Mediterranean region with an extensive representation in this biogeographic

67 region. In Spain, $Q$. pyrenaica represents the dominant species of different 68 vegetation series (del Río et al 2007).

69 Forest fragments of the study area are embedded in a matrix mainly 70 composed of heather Erica australis 1,560ha (1\%), brooms Genista florida and 71 Cytisus scoparius (hereafter $C$. scoparius) 3,640ha (3\%), meadows 3,460ha (3\%) 72 and riparian lowland forest of Populus nigra, Fraxinus excelsior and Alnus 73 glutinosa 5,340ha (4\%). Understory cover is mainly dominated by heath Erica 74 arborea (hereafter E. arborea) and broom C. scoparius while bilberry and holly is 75 completely absent or very scarce $(<0.5 \%$ of the forest ground cover $)$ in the study 76 area. The remaining $62 \%$ surface corresponds with anthropogenic landscapes such 
77 as villages, roads, opencast mines, valley bottoms, which are not suitable for

78 capercaillie habitat. Human population is approximately 1,000 people (0.6

79 people $/ \mathrm{km}^{2}$ ) and it has declined by $80 \%$ since the 1950 's. Livestock rearing is the

80 main economic activity in the study area, followed by coal mining industry,

81 agriculture, forestry and hunting.

\section{Methods}

84 No systematic sampling of the species was performed for the whole study

85 area. We gathered information on capercaillie presence from 2002-2009 from two

86 sources: i) questionnaires and reports sent by forest wardens, hunters and local

87 people to the León environmental agency from the regional government

88 (Consejería de Medio Ambiente of the Junta de Castilla y León), and ii) field

89 surveys. Samples were recorded over the whole year. Data from the first source

90 were validated within two weeks after receipt of the sample through field surveys

91 carried out by an experienced observer (L. Robles). Field surveys consisted of a 3-

924 hours systematic zig-zag walk looking for presence signs of capercaillie (e.g.,

93 direct sightings, footprints, droppings or feathers), especially focusing on sites

94 known to be highly used by the species (e.g., forest paths, dead trunks, big stones,

95 oldest forest sites, etc.).

96 In forest patches bigger than $1 \mathrm{~km}^{2}$ (i.e., more than 3-4 hours of sampling

97 required) we conducted surveys over consecutive days until covering the whole

98 forest patch (i.e., a continuous forest isolated by a non-forest matrix). Direct

99 sightings, footprints, droppings or feathers recorded in a site were considered as

100 signs of capercaillie presence. Each forest patch was completely surveyed 6-10

101 times throughout one year, 1-2 months each between. If no sign of capercaillie 
102 presence was found, the forest patch was labelled unoccupied and no further 103 surveys were conducted in that specific patch.

104 Additionally, we surveyed the occupied patches in order to find leks.

105 Selected sites were locations where survey after survey we found capercaillie 106 signs. The visits were performed throughout April and May (i.e., display season) 107 after 12 a.m. to avoid disturbing birds. A lek is defined as a site where one or 108 more cocks consistently display for hens, plus the adjacent surrounding forest 109 habitat. It has traditionally been used as capercaillie occurrence measure in the

110 Cantabrian range (see Obeso \& Bañuelos 2003).

111 During April-May where fresh capercaillie signs were found, 2-3

112 observers (forest wardens and L. Robles) visited the site at night as many as four

113 times until the display finished, or until well past dawn. A site was considered as

114 an occupied lek when at least one cock was heard calling or seen displaying.

115 Every detected lek was surveyed each year to label it as occupied or 116 unoccupied just looking for presence signs after 12 a.m. (see above). In April117 May 2009 every occupied lek was surveyed at night to get the number of 118 displaying cocks.

119 Nine forest structure variables (Table 1) were measured in each lek 120 consisting of twelve circular plots with $5 \mathrm{~m}$ radius. Three plots separated by 10 121 meters among them were arranged in each cardinal direction from the lek centroid 122 (i.e., the point where previously here a cock was recorded displaying). 
A total of nine leks, including that discovered in 1998 (Pollo et al 2004),

127 were registered in the study area, seven of them remained occupied in 2009 (Fig.

128 2). The highest occupancy was in 2006 with eight occupied leks (Fig. 2). Since 1292006 no new lek was found, despite an increase of around 2,000 additional 130 hectares surveyed (60\% of the total surveyed surface, Fig. 2). Leks were grouped

131 into three subareas according to the watersheds: one subarea had three leks, other

132 had four and the last subarea had two (Fig. 1). Mean nearest neighbour distance 133 between leks was $2.07 \pm 0.74$ kilometers (mean $\pm \mathrm{SE})$.

134 Leks were in Q. pyrenaica forests ranging from 1,132 to 1,398 m.a.s.l. 135 (mean \pm SE: $1275 \pm 100.93, \mathrm{n}=9$ ) and mainly faced in a northerly direction with 136 two exceptions facing south (Table 1). They showed heterogeneity in the forest 137 structure, ranging from sites with young trees (perimeter $0.19 \pm 0.005$ meters) 138 with high canopy cover $(0.81 \pm 0.06 \%)$ to mature trees (perimeter $0.90 \pm 0.62$ 139 meters $)$ with low canopy cover $(0.28 \pm 0.07 \%)$. The maximum tree height in leks 140 varied from $7.75 \pm 0.86$ meters to $16.50 \pm 3.20$ meters (see Fig. 3 ).

141 Understory cover ranged from low $(0.004 \pm 0.86 \%)$ to high $(0.62 \pm$ $1420.27 \%$ ). In six of the nine leks the dominant understory species was E. arborea 143 while $C$. scoparius dominated the remaining one (Table 1).

144 In 2009 twelve cocks were recorded at the seven occupied leks. Moreover, 145 two additional cocks not referred to any lek were detected during the spring 2009 146 fieldwork. Two nests with five and seven eggs each (both in $Q$. pyrenaica forest) 147 were found in early June 2009 (Fig. 1, No 5 and 8). 
151 So far, capercaillie always occurred in the Eurosiberian biogeographical

152 region with the exceptions of the probably introduced birds of Mount Athos

153 (Greece; Handrinos and Akriotis 1997), currently extinct (S. Xirouchakis per.

154 comm.), and two other unclear data in Mount Grammos and Lailias Forest

155 Reserve in Greece (Storch 2001). Therefore, the capercaillie population we

156 described here represents both the southern-most distribution for capercaillie and

157 the only one inhabiting Mediterranean $Q$. pyrenaica forests. These forests are

158 different from the nearest ones occupied by capercaillie leks located north of the

159 putative line separating Eurosiberian and Mediterranean regions (Fig 1, Table 1

160 and 2). These northern leks are mainly located in birch and sessile oak forests

161 with understory dominated by bilberry (see Table 2) in a Eurosiberian bioclimatic

162 environment (superior montane thermotype and inferior humid ombrotype) (Penas

163 1995). Nonetheless lek 4, although in Q. pyrenaica forest, has an eurosiberian

164 bioclimatic environment (Penas 1995), probably because of its most northerly 165 relative position.

166 Despite an increase in the surveyed area, no new leks were found after

167 2006. However, the fact that we only surveyed $12 \%$ of the forest surface within

168 our study area (Fig. 2), suggests new leks may be found in the future. Although

169 the number of capercaillie in the study area is small, it represents approximately

$1707 \%$ of the global Cantabrian population, highlighting the conservation value of

171 this site.

172 All the nine leks were located in Q. pyrenaica forests. Conversely no lek 173 was located in pure Scots pine plantations, although these were available in the 
174 study area. In addition, two of four radio-tracked (one hen and one cock) capers

175 used all year round Q. pyrenaica forests of the studied area (authors, unpublished 176 data) and two capercaillie nests were discovered in these forests. All of this

177 suggests that $Q$. pyrenaica forests are suitable year-round habitat for the 178 Cantabrian capercaillie. This is particularly important because the potential habitat 179 for this endangered subspecies could thus be greatly increased, as $Q$. pyrenaica 180 forests are highly represented with $>100,000$ hectares at the southern slope of the 181 Cantabrian Mountains (Gil-Sanchez \& Torre-Antón 2007). Additionally, despite 182 the idea that Q. pyrenaica forests are not considered as suitable habitat (Quevedo 183 et al. 2006b) and neither are included in the recovery plans for the Cantabrian 184 capercaillie, our study highlights the need to take into account these forests for the 185 conservation of this subspecies. Nonetheless, the role of the pine plantations for 186 capercaillie in the study area should be further assessed.

187 Finally, this study supports what is suggested by Quevedo et al. (2006a; 188 2006b) and Blanco-Fontao et al. (2009) that many general considerations for the 189 species overall are not fully useful for the Cantabrian capercaillie, and suggests a 190 wider adaptation and plasticity of this species than previously thought. For 191 example, the near absence of bilberry and holly in the studied area suggest that 192 capercaillie can maintain viable populations without this important summer and 193 winter food resource for Cantabrian population and elsewhere (Storch 2001; 194 Blanco-Fontao et al. 2009). Future research could address a detailed comparison 195 of capercaillie suitable habitat between the two different biogeographical regions. 196 Studying the ecology and genetic variability of this local population living in this 197 atypical habitat would be of a great value to further understand and conserve this 198 subspecies in particular and Tetrao urogallus in general. 
$201 \quad$ Zusammenfassung

202

203 Der Mediterrane Pyrenäen-Eichenwald: ein neuer Lebensraum für das

204 Auerhuhn?

205

206 Wir beschreiben eine Ausdehnung des bekannten Verbreitungsgebietes des

207 Auerhuhns in ein atypisches Gebiet und Habitat für diese Art. In einem 1,500 km²

208 großen Pyrenäen-Eichenwald Gebiet, wovon 4,500 ha Wald untersucht wurden,

209 konnten neun Balzarenen des Kantabrischen Auerhuhns Tetrao urogallus

210 cantabricus und 14 Hähne festgestellt werden. Aktuell repräsentiert diese

211 Population die sowohl südlichste Verbreitung von Auerhühnern als auch die

212 einzige, die mediterrane Pyrenäen-Eichenwälder bewohnt. Dieses weist auf eine

213 größere Anpassung dieser (Unter-)Art hin, als vorher vermutet. Diese Auerhuhn-

214 Population und ihr Lebensraum müssen jedoch noch besser untersucht werden

215 und sie sollte auch in Schutzstrategien für das Kantabrische Auerhuhn

216 berücksichtigt werden. 


\section{ACKNOWLEDGEMENTS}

The forest wardens Fernando Gonzalo, Álvaro Ortiz and Ramón Balaguer showed us many little known aspects of the $Q$. pyrenaica forests. We wish to thank to María Angeles Osorio and César Pollo from the Consejería de Medio Ambiente

de León of the Junta de Castilla y León. Particular thanks are due to Beatriz Blanco-Fontao, Patricia Mateo, Andy Dean and two anonymous reviewers whose revisions largely improved the manuscript. Manuel A. González is supported by a PhD scholarship of the Universidad de León. 


\section{LITERATURE CITED}

Bañuelos M J, Quevedo M (2008) Update of the situation of the Cantabrian capercaillie Tetrao urogallus cantabricus: an ongoing decline. Grouse News 25:57.

Blanco-Fontao B, Fernández-Gil A, Obeso J R, Quevedo M (2009) Diet and habitat selection in Cantabrian capercaillie: ecological differentiation of a rearedge population Journal of Ornithology in press.

Blondel, J., y Aronson, J. 1999. Biology and Wildlife of the Mediterranean Region. Oxford University Press, Oxford, UK.

Castroviejo J (1975) El urogallo en España. Monografías de la Estación Biológica de Doñana, CSIC.

Del Hoyo J, Elliot A, Sargatal J (ed) (1994) Handbook of the Birds of the World: New world vultures to guineafowl. Lynx Editions, Barcelona.

Del Rio S, Herrero L, Penas A (2007) Bioclimatic analysis of the Quercus pyrenaica forests in Spain. Phytocoenologia 37:541-560.

European Environment Agency (EEA). Biogeographical Regions, Europe 2008. http://www.eea.europa.eu/data-and-maps/data/biogeographical-regions-europe2008/ (accessed 15 October 2009).

Gil-Sánchez L, Torre-Antón M (ed). 2007. Atlas forestal de Castilla y León, Valladolid.

Guo Q, Taper M, Schoenberger M, Brandle J (2005) Spatial-temporal population dynamics across species range: from centre to margin. Oikos 108:47-57.

Handrinos G, Akriotis T (1997) The birds of Greece. Christopher Helm, London.

Helle P, Kurki S, Lindén H (1999) Change in the sex ratio of the Finnish capercaillie Tetrao urogallus population. Wildl Biol 5:25-31.

Madoz P (1848) Diccionario geográfico-estadístico-histórico de España y sus posesiones de ultramar. Madrid.

Martínez AM (1993) Contribución al conocimiento de la eco-etología del urogallo cantábrico. Universidad de León. León.

Obeso JR, Bañuelos MJ (2003) El urogallo (Tetrao urogallus cantabricus) en la Cordillera Cantábrica. Servicio de Publicaciones de Parques Nacionales. Ministerio de Medio Ambiente, Madrid. 
Penas A 1995. Atlas del Medio Natural de la provincia de León. Instituto Geominero de España.

Pollo CJ, Robles L, García-Miranda A (2004) Aumentan los urogallos "locos" en la cordillera Cantábrica. La Garcilla 119:20-21.

Quevedo M, Bañuelos MJ, Obeso JR (2006a) The decline of Cantabrian capercaillie: How much does habitat configuration matter?. Biol Conserv 127:190-200.

Quevedo M, Bañuelos MJ, Saez O, Obeso JR (2006b) Habitat selection by Cantabrian capercaillie Tetrao urogallus cantabricus at the edge of the species distribution. Wildl Biol 12:267-276.

Rivas-Martínez S, Loidi J (1999) Bioclimatology of the Iberian Peninsula. Itinera Geobot. 13:41-48.

Rivas-Martínez S, Penas A, Díaz T E (2004) Biogeographic Map of Europe. Cartographic Service. University of León, Spain. http://www.ucm.es/info/cif/form/bg_med.htm (accessed 10 September 2009).

Rivas-Martínez S et al. (2005). Mapa de series, geoseries y geopermaseries de vegetación de España. Memoria del mapa de vegetación potencial de España. Parte 1.

http://www.ucm.es/info/cif/book/mapa_series/mapa_series_01.pdf (accessed 10 September 2009).

Storch I (1993) Habitat selection by capercaillie in summer and autumn: Is bilberry important?. Oecologia 95:257-265.

Storch I (2000a) Conservation status and threats to grouse worldwide: an overview. Wildl Biol 6:195-204.

Storch I (2000b) Status Survey and Conservation Action Plan 2000-2004: Grouse. WPA/BirdLife/SSC Grouse Specialist Group. IUCN, Glan, Switzerland and Cambridge, UK, and the World Pheasant Association, Reading, UK.

Storch I (2001) Capercaillie. Pages 1-24 in O. U. Press, editor. BWP Update: The journal of birds of the Western Palearctic. Oxford, UK.

Storch I, Bañuelos MJ, Fernandez-Gil A, Obeso JR, Quevedo M RodriguezMuñoz R (2006) Subspecies Cantabrian capercaillie Tetrao urogallus cantabricus endangered according to IUCN criteria. J Ornithol 147:653-655. 


\section{APPENDIX}

Appendix 1. Description of the leks ( $n=9)$ in the study area (see $\bullet$ in the map of the study area). Mean \pm SE are shown for forest structure variables of the leks.

Footnote: Lek = lek number by discovery date; Date = year when the lek was first-time recorded (April-May); Cocks = No. of capercaillie cocks recorded in each lek in 2009; m. a. s. l. = elevation (meters above the sea level); Exp. = exposure in the slope; Tree Perimeter $=$ mean trees perimeter measured in DBH (diameter at breast height). Tree Height $=$ mean trees height; Cover $=$ mean canopy cover $(\%)$; Species $=$ tree dominant species; Height = mean understory height (meters); Cover = mean understory cover $(\%)$; Species $=$ understory dominant specie.

\begin{tabular}{|c|c|c|c|c|c|c|c|c|c|c|c|}
\hline \multirow[b]{2}{*}{ Lek. } & \multirow[b]{2}{*}{ Date } & \multirow[b]{2}{*}{ Cocks } & \multirow[b]{2}{*}{ m a.s. 1.} & \multirow[b]{2}{*}{ Exp. } & \multicolumn{4}{|c|}{ Trees } & \multicolumn{3}{|c|}{ Understory } \\
\hline & & & & & Perimeter (m) & Height (m) & Cover $(\%)$ & Species & Height $(\mathrm{m})$ & Cover $(\%)$ & Species \\
\hline 1 & 1998 & 2 & 1215 & NW & $0.45 \pm 0.17$ & $9.42 \pm 1.38$ & $0.57 \pm 0.21$ & Q. pyrenaica & $1.12 \pm 0.38$ & $0.39 \pm 0.25$ & C. scoparius \\
\hline 2 & 2002 & 1 & 1131 & NW & $0.90 \pm 0.62$ & $16.50 \pm 3.20$ & $0.58 \pm 0.15$ & $Q$. pyrenaica & $0.85 \pm 0.07$ & $0.25 \pm 0.06$ & C. scoparius \\
\hline 3 & 2002 & 0 & 1154 & NW & $0.32 \pm 0.15$ & $9.17 \pm 1.75$ & $0.54 \pm 0.26$ & $Q$. pyrenaica & $0.75 \pm 0.50$ & $0.16 \pm 0.17$ & E. arborea \\
\hline 4 & 2003 & 2 & 1230 & $\mathrm{NE}$ & $0.70 \pm 0.13$ & $7.75 \pm 0.86$ & $0.28 \pm 0.07$ & Q. pyrenaica & $1.33 \pm 0.24$ & $0.45 \pm 0.25$ & E. arborea \\
\hline 5 & 2004 & 3 & 1387 & $\mathrm{~N}$ & $0.70 \pm 0.15$ & $14.08 \pm 2.81$ & $0.64 \pm 0.22$ & $Q$. pyrenaica & $0.03 \pm 0.08$ & $0.004 \pm 0.01$ & C. scoparius \\
\hline 6 & 2006 & 1 & 1253 & $\mathrm{~N}$ & $0.20 \pm 0.05$ & $9.50 \pm 0.42$ & $0.60 \pm 0.25$ & $Q$. pyrenaica & $0.50 \pm 0.42$ & $0.51 \pm 1.41$ & E. arborea \\
\hline 7 & 2006 & 0 & 1356 & $\mathrm{~N}$ & $0.23 \pm 0.06$ & $11.17 \pm 0.38$ & $0.47 \pm 0.24$ & Q. pyrenaica & $0.79 \pm 0.25$ & $0.39 \pm 0.57$ & E. arborea \\
\hline 8 & 2006 & 2 & 1351 & SE & $0.43 \pm 0.10$ & $10.33 \pm 1.37$ & $0.58 \pm 0.15$ & $Q$. pyrenaica & $1.37 \pm 0.31$ & $0.40 \pm 0.17$ & E. arborea \\
\hline 9 & 2006 & 1 & 1398 & SW & $0.19 \pm 0.05$ & $10.16 \pm 0.57$ & $0.81 \pm 0.06$ & Q. pyrenaica & $1.42 \pm 0.45$ & $0.62 \pm 0.27$ & E. arborea \\
\hline
\end{tabular}


Appendix 2. Description of the Eurosiberian leks $(n=17)$ north of the study area (see Fig 1). Mixed in "Tree species" involves no tree species as dominant, but occurring mixed: Betula pubescens, Q. petraea, Q. pyrenaica and Sorbus aucuparia.

\begin{tabular}{|c|c|c|c|c|}
\hline Lek & m.a.s.l. & Exposure & Tree species & Understory species \\
\hline 1 & 1440 & $\mathrm{~N}-\mathrm{W}$ & Q. petraea & Vaccinium myrtillus \\
\hline 2 & 1520 & $\mathrm{~N}-\mathrm{W}$ & Mixed & Vaccinium myrtillus \\
\hline 3 & 1450 & $\mathrm{~N}-\mathrm{W}$ & Mixed & Vaccinium myrtillus \\
\hline 4 & 1550 & N-E & Mixed & Vaccinium myrtillus \\
\hline 5 & 1490 & $\mathrm{~N}$ & Q. petraea & Vaccinium myrtillus \\
\hline 6 & 1620 & $\mathrm{~N}$ & Betula pubescens & Erica arborea \\
\hline 7 & 1650 & $\mathrm{~N}$ & Betula pubescens & Erica arborea \\
\hline 8 & 1550 & $\mathrm{~N}$ & Betula pubescens & Erica arborea \\
\hline 9 & 1680 & $\mathrm{~N}$ & Betula pubescens & Erica arborea \\
\hline 10 & 1590 & N-E & Betula pubescens & Vaccinium myrtillus \\
\hline 11 & 1680 & $\mathrm{~N}$ & Betula pubescens & Vaccinium myrtillus \\
\hline 12 & 1620 & $\mathrm{~N}-\mathrm{W}$ & Mixed & Vaccinium myrtillus \\
\hline 13 & 1540 & $\mathrm{~N}-\mathrm{W}$ & Mixed & Vaccinium myrtillus \\
\hline 14 & 1510 & $\mathrm{~N}-\mathrm{W}$ & Betula pubescens & Erica arborea \\
\hline 15 & 1590 & $\mathrm{~N}$ & Betula pubescens & Erica arborea \\
\hline 16 & 1620 & $\mathrm{~N}-\mathrm{E}$ & Betula pubescens & Vaccinium myrtillus \\
\hline 17 & 1590 & $\mathrm{~N}-\mathrm{W}$ & Mixed & Vaccinium myrtillus \\
\hline
\end{tabular}




\section{FIGURE LEGENDS}

FIG. 1. Area of occupancy of Cantabrian capercaillie in 1980 (Obeso \& Bañuelos 2003) (black left) and study area (right). Numbers correspond to the leks according to the discovery date. Lek 1 was the first capercaillie breeding record in Q. pyrenaica forest in 1998. Solid line represents the border between the Eurosiberian and the Mediterranean biogeographical regions after European Environment Agency -EEA- 2008 and Rivas-Martínez et al (2004). (•) represent the recently discovered Mediterranean leks while $(\boldsymbol{\Delta})$ represent the traditional Eurosiberian leks. According to the government restrictions, leks location is slightly moved for security. Light and dark grey dominating the area represents Pinus sylvestris and $Q$. pyrenaica forests, respectively.

FIG. 2. Occurrence of the Mediterranean leks since 2002. Bars show the total accumulated forest surface surveyed (ha) through the study years. Solid line represents the occupied leks and broken line the known leks. 
FIG. 1

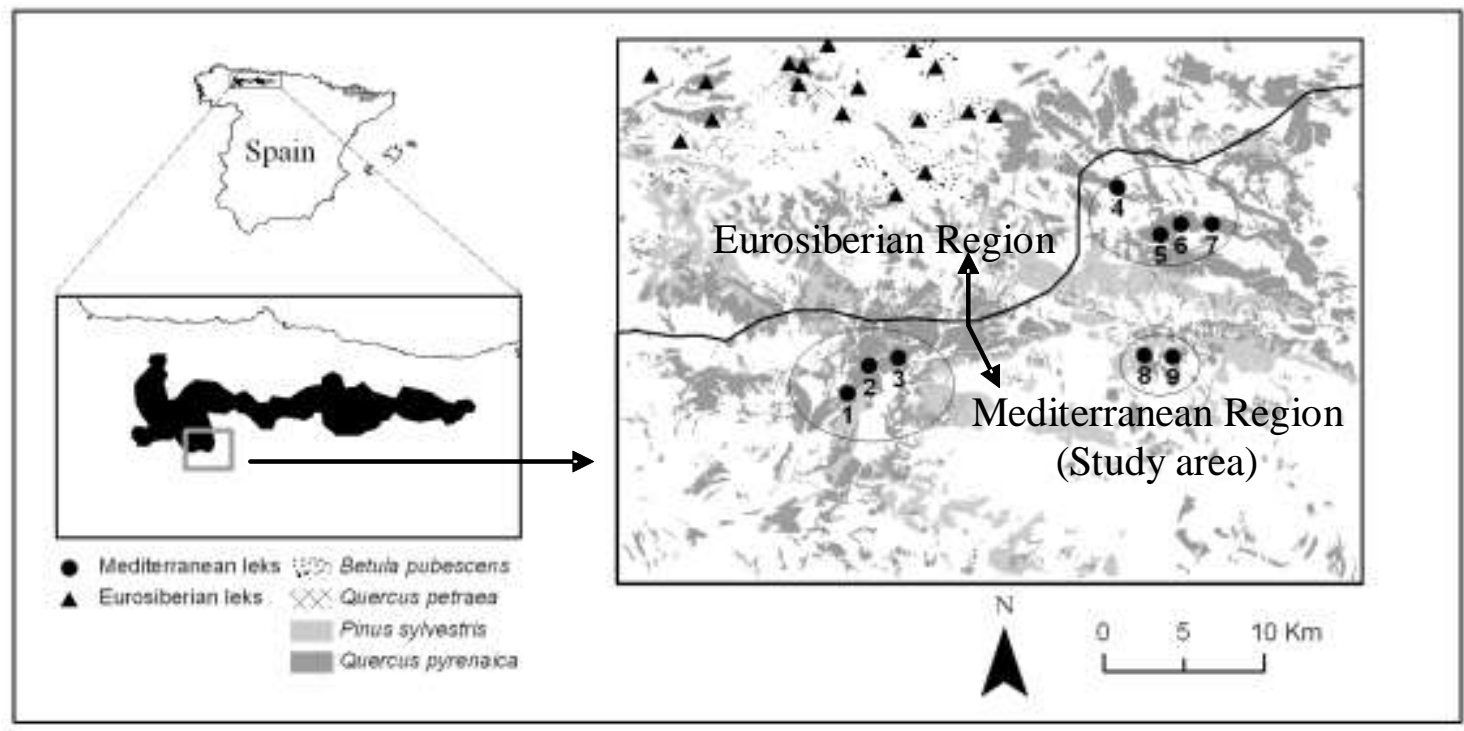

FIG. 2

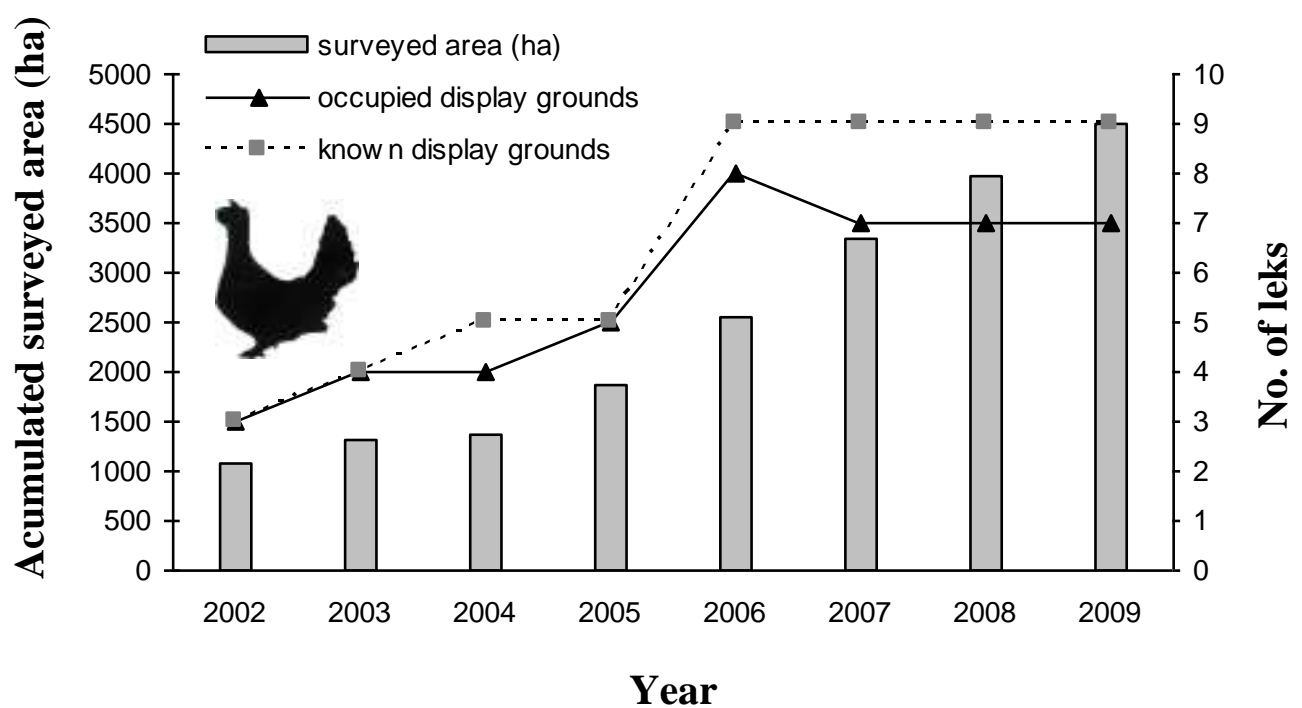

